\title{
Mucous Membrane of the Rumen of Ovines, Fed With Spineless, Forrage Cactus or Palm (Barbary Fig) (Opuntia ficus indica Mil): Hystochemical Study by Means of Light Microscopy
}

\author{
Membrana Mucosa del Rumen de Ovinos, Alimentados con Forraje de Cactus Sin Espinas o Palmeras \\ (Barbary Fig) (Opuntia ficus indica Mil): Estudio Histoquímico por Medio de Microscopía de Luz
}

*Gentileza Santos Martins Neiva; ${ }^{* *}$ Diógenes Luís da Mota; ${ }^{* * *}$ Ângela Maria Vieira Batista \& ${ }^{* * * *}$ Célio Fernando de Sousa-Rodrigues

NEIVA, M. G. S.; DA MOTA, D. L.; BATISTA, V. A. M. \& SOUSA-RODRIGUES, C. F. Mucous membrane of the rumen of ovines, fed with spineless, forrage cactus or palm (Barbary fig) (Opuntia ficus indica Mil): Hystochemical study by means of light microscopy. Int. J. Morphol., 24(4):723-728, 2006.

SUMMARY: The mucosa of the rumen performs the functions of absorption, transportation, metabolism and protection, due to the presence of microorganisms in this compartment of the digestive tract, which are responsible for the digestion of approximately $60 \%$ of the organic material apparently digested. The histological structure and the histochemical profile of glicoconjugate of the mucosa of the stomach of sheep that were being fed with forrage cactus or palm (Giant Palm - Opuntia ficus indica Mil)1. Twelve sheep were used, with approximately 14 months old, which were oddly distributed in four diets: $\mathrm{D}_{1}-60.0 \%$ forrage palm $+40.0 \%$ concentrated ration; $\mathrm{D}_{2}$ $47.5 \%$ forrage palm $+12.5 \%$ elephant, napier grass $+40.0 \%$ concentrated ration, and $\mathrm{D}_{3}-34,8 \%$ forrage palm $+25.2 \%$ elephant, napier grass $+40.0 \%$ concentrated ration and $\mathrm{D}_{4}-60.0 \%$ elephant, napier grass $+40.0 \%$ concentrated ration. The experience period lasted 90 days, and, at the end, the animals were euthanized and fragments of different compartments of their stomachs were taken right after. The animals having consumed diets $\mathrm{D}_{1}, \mathrm{D}_{2}$ e $\mathrm{D}_{3}$ presented more developed papillas, while the ones of diet $\mathrm{D}_{4}$, presented less developed papillas. The stratum corneum of the epithelium of the rumen coating of the animals in diet $\mathrm{D}_{1}$ presented a slight erosion, when compared to those in diets $\mathrm{D}_{2}, \mathrm{D}_{3}$ and $\mathrm{D}_{4}$.

KEYWORDS: Mucous membrane; Histology; Histochemistry; Forrage palm; Forrage cactus; Ovine.

\section{INTRODUCTION}

The mucosa of the rumen performs the absorption, transportation, metabolism and protection. Due to the presence of microorganisms in this compartment of the digestive tract, which are responsible for the digestion of around $60 \%$ of the organic material which is apparently digested, and due to the constant changes in the fermentation products, the rumen mucous membrane have a great adaptation capability to internal and external conditions. In this compartment, the epithelium is stratified squamous keratinized, its width is varied and the layers are not well defined. The keratinized superior layer forms a protection shield against the rough and fibrous food, while the deeper layers metabolize the volatile fatty and short-chain acids, especially the butyric, acetic and propionic, which are the main products of fermentation (Stinson et al., 1982).

The internal surface of the rumen has small papillas with variable heights, which can reach $1.5 \mathrm{~cm}$ length in an adult bovine. The size and frequency of the papillas vary considerably according to the region of the rumen. They are generally more dense in the central parts of the dorsal and ventral bags, where we assume that there is a greater absorption. These papillas remain little developed while the animal is a suckling, and will rapidly increase, when rough food is included in the diet, and the fermentation starts in the rumen (Brownlee, 1956; Sander et al., 1959).

* Veterinary Physician, Assistant Professor of the Department of Morphology of UFAL, Brasil.

** Biomedical researcher, PhD., Department of Histology at UFPE and of Morphological Sciences, Brasil.

*** Zootechnician, Assistant Professor at the Department of Animal Nutrition at UFRPE, Brasil.

***** Professor of the Anatomy Laboratory of UFAL, Brasil.

Part of the thesis presented at UFRPE as part of the requirements for the title of Master in Animal Production. This project was partially financed by FACEPE, Brasil. 
The development of the mucosa depends on the type of food the animal receives. Diets that are rich in carbohydrates, easily digested, and with a low fiber content, result in the production of a higher amount of propionic and butyric acids, which will trigger a greater development in young animals and a greater proliferation in adult animals.

Studies with goats show that, although the weight of the forestomachs is delayed by the prolonged feeding with milk, the normal histological changes of their age still followed their course at the rumen-reticullum; the omasum, although, remained in juvenile state until solid food was administered, and the histology the wall of the omasum changed rapidly, Tratmann em 1932, quoted by Wardrop (1961).

Although the production of fatty acids is responsible for the normal development of the papillas, the high concentration of acids in the diet, the exceeding production of lactic acid, associated to the low production of saliva and reduction of the tamponing capability can result in the incidence of parakeratosis. Chronic acidosis was also reported in the abomasum syndrome (van Soest, 1994).

Diets composed by forrage palm and concentrated ration are low in fiber and require a high digestion rate, which can probably explain the observed diarrhea, the reduction in the fat content of the milk, and the abdominal tympanism reported by cattle raisers who use the palm in the ration of their dairy cows. These diets, when administered for long periods, could also lead to the incidence of problems in the rumen's mucosa. Thus, the present work had the purpose to evaluate the histological structure and the histochemical profile of glycoconjugates of the mucosa of the rumen of sheep which consume rations with a high content of forrage palm.

\section{MATERIAL AND METHOD}

We used twelve sheep, with no defined breed, around 14 months old, which were oddly distributed in four groups of three each, with the diets: $D_{1}-60,0 \%$ forrage palm $+40,0 \%$ concentrated ration; $\mathrm{D}_{2}-47,5 \%$ forrage palm $+12,5 \%$ elephant, napier grass $+40,0 \%$ concentrated ration and $\mathrm{D}_{3}-34,8 \%$ forrage palm $+25,2 \%$ elephant, napier grass $+40,0 \%$ concentrated ration and $\mathrm{D}_{4}-60,0 \%$ elephant, napier gras $+40,0 \%$ concentrated ration. The ration was divided in two equal parts, which were offered at 8 am and $4 \mathrm{pm}$. The experience period lasted 90 days, 20 of them for the adapting of the animals to the feed, and to its experimental handling, and 70 days of experimental diets. At the end, the animals were euthanized and, after the opening of the abdominal cavity, the different compartments of the stomach were identified (rumen, reticulum, omasum and abomasum) Fragments of the rumen were taken and fixed in Bouin liquid for 24 hours, dehydrated in absolute alcohol, diaphanized in xylol, and included in paraffin wax. Sections of approximately $6 \mu \mathrm{m}$ width were submitted to Hematoxylin coloration - Eosyn and Picro -Sirius, according to the method of Junqueira \& Carneiro (1990) for morphological studies. The following methods were used for the histochemical study of the mucins: 1. Periodic acid-Schiff (PAS), McManus (1946); 2. PAS after the enzimatic digestion by saliva amylase, Lison (1960); 3. PAS with block by acetillation and after saponification, McManus \& Cason (1950); 4. Alcian Blue (A.B.) at 3\% in acetic acid, Spicer (1960), before and after methylation, Fisher \& Lillie (1954); followed by saponification, Lillie \& Fullmer (1976); and Alcian Blue at 3\% in $\mathrm{HCl} 0,1 \mathrm{~N}, \mathrm{pH} 0.5$, Lev \& Spicer (1964).

\section{RESULTS}

In this experiment, the animals having consumed all diets presented the general histological pattern for most of the mammals, with mucous, sub-mucous, muscular and serous tunics. The mucosa of the rumen, reticulum and omasum consisted of four cell stracta: the basal, formed by cyllindric cells disposed in an only layer; the stractum spinosum, formed by poliedric cells, slightly larger than the basal cells, stractum granulosum, with flattened cells and granules of queratohyaline, present in the citoplasma, and the stratum corneum, whose width varied from one to twenty cells. The cells had a squamous form, and their colorable nucleus could be present or not. The mucosa of the abomasum, at the fundic region, was constituted by simple cylindrc epithelium, and by its lamina propria of conjunctive tissue, filled in almost all its width by glands. The epithelium invaginated, forming small pits in which the glands emptied. The glands were tubular and finished near the muscularis mucosae. In the piloric region, the pits were deeper and the glands shorter, with a greater number of mucous cells.

Our results showed that, macroscopically, we could observe that the animals in diets with forrage palm + concentrated ration, $\left(\mathrm{D}_{1}, \mathrm{D}_{2} \mathrm{e} \mathrm{D}_{3}\right)$, presented more developed papillas and a yellow-colored mucosa, while those who consumed gras and concentrated ration (control group) presented smaller papillas and green-brownish mucosa. Under the light microscope, we verified that, in the groups that received diet $\mathrm{D}_{4}$ (control) and $\mathrm{D}_{1}$ (forrage palm + concentrated ration) the stratum granulosum of the papillar epithelium was slightly more developed and had a less eroded aspect compared to diets $\mathrm{D}_{2}$ and D3 (Figs. 1 and 4 ). In the animals in diets $D_{2}$ and $D_{3}$ (forrage palm + grass + concentrated ration) the stratum spinosum was less dense, while the stratum corneum was more eroded and presented quite vaculoated cells (Figs. 2 and 3).

In Tables I and II, we expose the histochemical results obtained in the four groups of studied animals. 
Table I. Results of the histochemical reactions for the detection of the glicoconjugates in the rumen of ovine, submitted to different diets.

\begin{tabular}{|c|c|c|c|c|}
\hline Fundic region & $D_{1}$ & $\mathrm{D}_{2}$ & $\mathrm{D}_{3}$ & $\mathrm{D}_{4}$ \\
\hline PAS & ++ & ++ & ++ & + \\
\hline Amylase + PAS & ++ & ++ & ++ & + \\
\hline A cetylation + PAS & - & - & - & - \\
\hline A cetylation + saponification+PAS & ++ & ++ & ++ & + \\
\hline A.B. $\mathrm{pH}=2.5$ & + & + & + & ++ \\
\hline A.B. $\mathrm{pH}=0.5$ & \pm & \pm & \pm & \pm \\
\hline Methylation + A.B. $\mathrm{pH}=2.5$ & - & - & - & - \\
\hline Methylation + saponification + A.B. $\mathrm{pH}=2.5$ & + & + & + & ++ \\
\hline
\end{tabular}

$\mathrm{D}_{1}-60.0 \%$ forrage palm $+40.0 \%$ concentrated ration. $\mathrm{D}_{2}-47.5 \%$ forrage palm $+12.5 \%$ elephant gras $+40.0 \%$ concentrated ration. $\mathrm{D}_{3}-34.8 \%$ forrage palm $+25.2 \%$ elephant gras $+40,0 \%$ concentrated ration. $\mathrm{D}_{4}-60.0 \%$ elephant gras $+40.0 \%$ concentrated ration Qualitative degree of the reactions: $(++)$ positive; (+) slightly positive; (-) negative; $( \pm)$ slight traces.

Table II. Results of the histochemical reactions for the detection of the glicoconjugates in the rumen of ovines, submitted to different diets.

\begin{tabular}{lcccc}
\hline \multicolumn{1}{c}{ Piloric region } & $\mathrm{D}_{1}$ & $\mathrm{D}_{2}$ & $\mathrm{D}_{3}$ & $\mathrm{D}_{4}$ \\
\hline PAS & ++ & ++ & ++ & + \\
Amylase + PAS & ++ & ++ & - & - \\
Acetylation + PAS & - & - & ++ & + \\
Acetylation + saponification + PAS & ++ & ++ & + & + \\
A.B. $\mathrm{pH}=2.5$ & + & + & - & - \\
A.B. $\mathrm{pH}=0.5$ & \pm & - & + \\
Methylation + A.B. $\mathrm{pH}=2.5$ & - & + & + \\
Methylation + saponification + A.B. $\mathrm{pH}=2.5$ & + & + & +
\end{tabular}

$D_{1}-60.0 \%$ forrage palm $+40.0 \%$ concentrated ration. $D_{2}-47.5 \%$ forrage palm $+12.5 \%$ elephant gras $+40.0 \%$ concentrated ration. $\mathrm{D}_{3}-34.8 \%$ forrage palm $+25.2 \%$ elephant gras $+40,0 \%$ concentrated ration. $\mathrm{D}_{4}-60.0 \%$ elephant gras $+40.0 \%$ concentrated ration. Qualitative degree of the reactions: $(++)$ positive; (+) slightly positive; $(-)$ negative; $( \pm)$ slight traces.

\section{DISCUSSION}

The histological general pattern of the stomach of ovine is similar to most of the ruminants. The influence of the diet consumed by the animal, regarding changes in the mucosa, is directly related to the volatile fatty acids producted in the rumen. Diet changes result in favorable conditions for the growth if certain microorganisms, and consequently, the fermentation products will be different. The fatty acids, the propionic and the butyrate, perform a fundamental role in the changes of the rumen's mucosa, with the increase in the size of the papilla, in the width of the mucosa, including the incidence of papillar bodies and para-nuclear valcuoles (Wardrop, 1961; Tamate et al., 1962; Harrison et al., 1960; Sutton et al., 1963). The changes observed in the gastric epithelium of animals in the different diets are caused by the diet-type differences. In animals receiving palm + concentrated ration, the production of propionate was higher (Neiva,1996), which justifies the greater development of the rumen mucosa in these animals. The vegetal food seems necessary to the total development of the histological structure of the rumen; different foods can alter the appearance of the surface of the mucosa of this organ (Brownlee, 1956), and can affect the histological structure of the granulosum and corneum strata. The most prominent abrasive materials in vegetal tissues are undoubtedly the "opal phytoliths" (Smithson, 1958; Baker et al., 1961). Since the grasses have a relatively high content of sillica, this may explain the difference in the erosion of the stratum corneum among the diets $\mathrm{D}_{1}$, $\mathrm{D}_{2}, \mathrm{D}_{3}$ and $\mathrm{D}_{4}$, as observed in the figures $1,2,3$ e 4 . Morphologically, the surface of the rumen epithelium of 

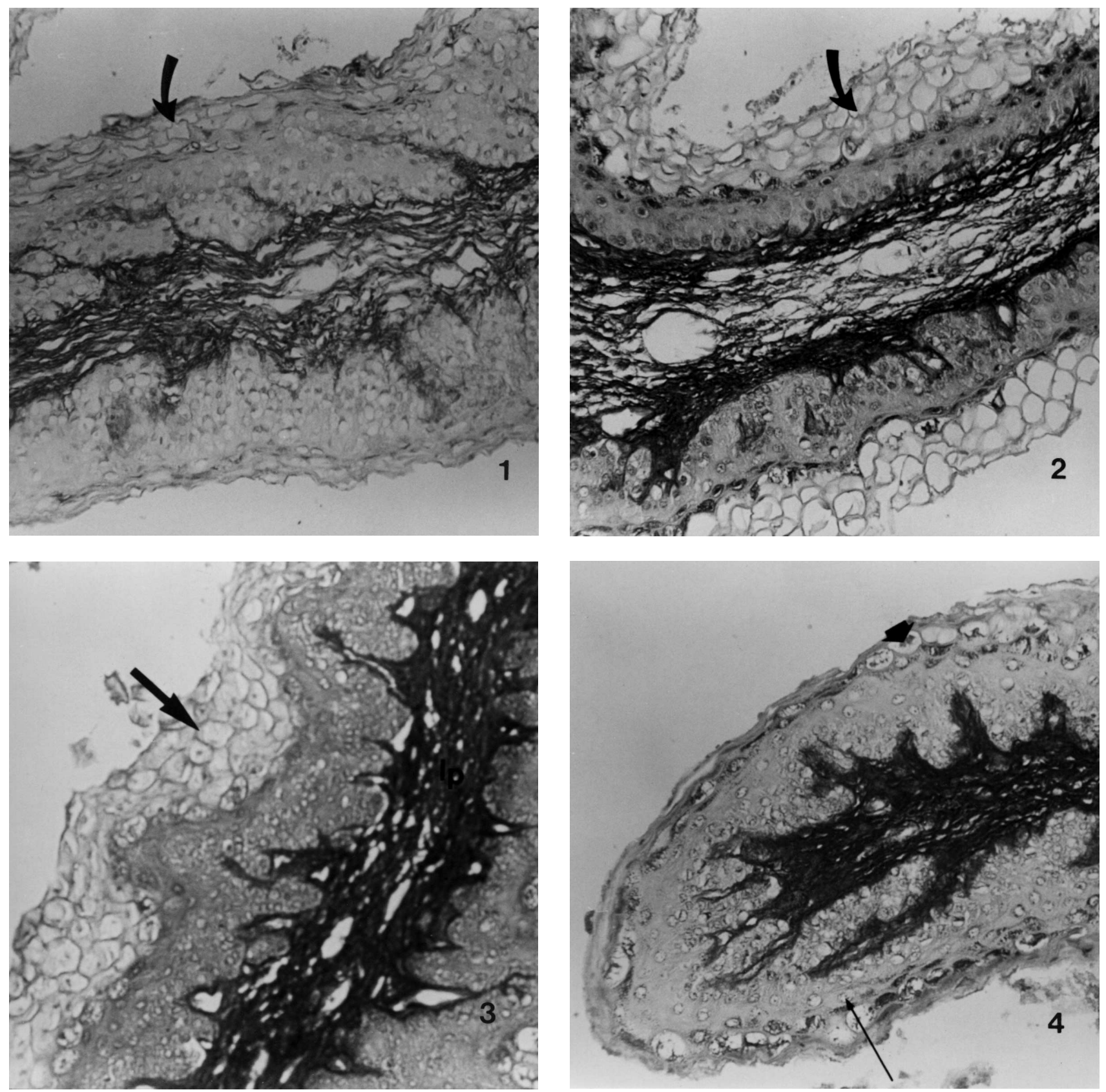

Fig. 1. Photomicrography of the rumen mucous in sheep under $\mathrm{D}_{1}$ diet. Volumous cells on the granulous (arrow), keratinous layer with vacuolated cells and less scaling (arrow) as compared to previous Figures. Picrosirius.

Fig. 2. Photomicrography of rumen mucous in the $\mathrm{D}_{2}$ diet. In the rumen epithelium a large area of scaling on the keratinous layer (arrow). Own lamina (lp). Picrosirius. 148x.

Fig. 3. Photomicrography of rumen mucous of sheep under $\mathrm{D}_{3}$ diet. Rumen epithelium with intense scaling of cell on the keratinous layer (arrow). Picrosirius. 148x.

Fig. 4. Photomicrography of rumen mucous in sheep under $\mathrm{D}_{4}$ diet. Rumen epithelium with scaling cells on the keratinous layer (arrow). Picrosirius. 148x.

the animals in diet $\mathrm{D}_{1}$ was much less eroded than the one of the animals in diet $\mathrm{D}_{4}$. This probably happened due to the sillica content of the grass, and its rougher physical structure, which provokes a greater friction among the particles of food and the mucosa. Considering the very low fiber content in diet $\mathrm{D}_{1}$, we could expect the incidence of parakeratosis in the animals that consumed this diet, as it has been reported in animals receiving concentrated diets 
(Orskov, 1986; Bull et al., 1965). This didn't happen, though. It is possible that the sillica content, or the content of other mineral substances in the forrage palm, have avoided the incidence of digestive problems. The intense erosion observed in the coating epithelium cells of the animals in diets $\mathrm{D}_{2}$ and $\mathrm{D}_{3}$, compared to the animals in diets $\mathrm{D}_{1}$ and $\mathrm{D}_{4}$, are possibly due to the association of the forrage palm and the elephant grass. Since these have a high sillica content, and isolatedly, had an abrasive effect on the mucous membrane; when offered together, they may have increased this effect.

Histochemical comparative studies (Willems \& Gerard, 1969; Sheahan \& Jervis, 1976), reveals the presence of similar complexes of polyssaccharides (glicoconjugates) in the stomach of apes, dogs, cats, desert rats, baboons, rabbits, pigs, guinea pigs, hamsters, mice and humans. In marsupials (Krause et al., 1976; Gemmel \& Engelhardt, 1977; Carvalho et al., 1987; Carvalho et al., 1989) and also in the armadillo Dasypus novemcinctus
(Carvalho et al., 1975) similar results with some differences in the intensity of the reactions were reported, probably due to the sensibility of the methodology to the fixation conditions and to the particularities and feeding habits of each species. Our findings suggest a possible change in the histochemical profile of the neutral mucosubstances, probably in response to the changes in the diet of the animals which received the forrage palm. Nevertheless, new studies are necessary to specifically feature these glicoproteins.

Based on the results of this work, we can conclude that:

1. Forrage palm in the ration of ovine triggered a greater development of the papillas.

2. The association of forrage palm and elephant grass in the ovine diet causes a greater erosion in the stratum corneum.

3. The influence of the diet on the structural pattern of the mucosa of the rumen was proved.

NEIVA, M. G. S.; DA MOTA, D. L.; BATISTA, V. A. M. \& SOUSA-RODRIGUES, C. F. Membrana mucosa del rumen de ovinos, alimentados con forrage de cactus sin epinas o palmeras (Barbary Fig) (Opuntia ficus indica Mil): Estudio histoquímico por medio de microscopía de luz. Int. J. Morphol., 24(4):723-728, 2006.

RESUMEN: La mucosa del rumen actúa en la absorción, transporte, metabolismo y protección, debido a la presencia de microorganismos en este compartimiento del tracto digestivo, los cuales son responsables de la digestión de aproximadamente el $60 \%$ de material orgánico aparentemente digerido. Se analizó la estructura histológica y el perfil histoquímico de las estructuras de glicoconjugados de la mucosa del estómago de las ovejas que fueron alimentadas con forraje de cactus o palmeras (Giant Palm - Opuntia ficus indica Mil)1. Fueron utilizadas 12 ovejas, con aproximadamente 14 meses de edad, las cuales fueron distribuidas de manera impar en cuatro dietas: $\mathrm{D}_{1}$ $60.0 \%$ forraje de palmera $+40.0 \%$ ración concentrada; $\mathrm{D}_{2}-47.5 \%$ forraje de palmera $+12.5 \%$ hierba alta africana $+40.0 \%$ ración concentrada, y $\mathrm{D}_{3}-34,8 \%$ forraje de palmera $+25.2 \%$ hierba alta africana $+40.0 \%$ ración concentrada y $\mathrm{D}_{4}-60.0 \%$ hierba alta africana $+40.0 \%$ ración concentrada. La experiencia duró 90 días y al final, los animales fueron sacrificados y fragmentos de diferentes compartimientos de sus estómagos fueron directamente recogidos. Los animales que habían consumido dietas $\mathrm{D}_{1}, \mathrm{D}_{2}$ y $\mathrm{D}_{3}$ presentaron papilas más desarrolladas, mientras que los alimentados con dieta $\mathrm{D}_{4}$ presentaron papilas menos desarrolladas. El estrato córneo del epitelio del rumen de los animales de la dieta $\mathrm{D}_{1}$ presentaron pequeña erosión, cuando fueron comparados con los animales sometidos a las dietas $\mathrm{D}_{2}, \mathrm{D}_{3}$ y $\mathrm{D}_{4}$.

PALABRAS CLAVE: Membrana mucosa; Histología; Histoquímica; Forraje de palmera; Forraje de cactus; Ovino.

\section{REFERENCES}

Banks, W. J. Sistema Digestivo. In: Histologia Veterinária Aplicada. $2^{\text {nd. }}$ ed. Manole, Rio de Janeiro, 1992. pp. 43954.

Baker, G.; Jones, L. H. P. \& Wardrop, I. D. Opal phytoliths and mineral particles in the rumen of the streep. Aust. J. Agric. Res., 12:462-72, 1961

Brownlee, A. The development of rumen papilae in cattle fed on different diets. The British Veterinary J., 112, (9):369-75, 1956.
Bull, L. S.; Bush, L. J.; Friend, J. D.; Harris, Jr., B. \& Jones, E. W. Incidence of ruminal parakeratosis in calves fed different ration and its relation to volatile fatty acid absorption. J. of Dairy Science, 48(11):1459-66, 1965.

Carvalho, A. D.V.; Rangel, N. M. \& Vignoli,V. V. Histochemistry of glicoproteins in the gastric epithelium of the fundic and body region of Dasypus novemcinctus. Rev. Brasileira de Pesquisas Médicas e Biológicas, 8:109-17, 1975. 
Carvalho, A. D. V. ; Magalhães, M. J. \& Moreira, M. C. Aspectos histológicos, histopatológicos e histoquímicos de mucinas do epitélio gástrico da região pilórica de Philander opossum. Rev. Bras. Cs. Morfol., 4:111-4, 1987.

Carvalho, A. D.V.; Magalhães, M. J. \& Filho, J. S.A. Histologia, histopatologia e histoquímica de mucinas do fundo e do corpo do estômago em Philander opossum. Rev. Bras. Cs. Morfol., 6:38-42, 1989.

Fisher, E. R. \& Lillie, R. D. Effect of methylation on basophilia. J. Histochemistry and cytochemistry, 2: $18,1954$.

Gemmel, R. T. \& Engelhardt, W. V. The structure of the cells lining of the stomach of the Tammar Wallby (Macropus engenii). J. Anat., 123:723-33, 1977.

Harrison, H. N.; Warner, R. G.; Sander, E. G.; Loosli, J. K. Changes in the tissue and volume of the stomachs of calves following the removal of dry feed or consumption of inert bulk. J. Dairy Science, 43:1301$12,1960$.

Junqueira, L. C. \& Carneiro, J. Histologia básica. $8^{\mathrm{a}}$ ed. Guanabara Koogan, Rio de Janeiro, 1990.

Krause, W. J.; Cutts, J. H. \& LE, C. R. The postnatal development of the alimentary canal in the opossum. II. Stomach. J. Anat., 122:499-519, 1976.

Lev, R. \& Spicer, S. S. Specific staining of sulphate groups with alcian blue at low $\mathrm{pH}$. J. Histochemistry and cytochemistry, 12:309, 1964.

Lillie, R. D. \& Fullmer, H. M. Histopathologic technic and practical histochemistry. Mc-Grac Hill Book Company, 1976.

Lison, L. Histochgimie etcytochimie animales. $3^{\text {a. }}$ ed. GrathierVillars, 1960.

McManus, J. F. A. Histological demonstration of mucin after periodic acid. Nature, 158:202, 1946.

McManus, J. F. A. \& Cason, J. E. Carbohydrate histochemistry studied by acetylation techniques. I. Exp. med., 91:6514, 1950 .

Neiva, G. S. M. Teores de ácidos graxos voláteis no líquido ruminal; histologia e histoquímica da mucosa do estômago de ovinos recebendo palma forrageira (Opuntia fícus indica Mill).1996. 49p. Dissertação de MestradoUniversidade Federal Rural de Pernambuco, Brasil.
Orskov, E. R. Starch digestion and utilization in ruminants. J. of Animal Science, 63:1624-33, 1986.

Sander, E. G.; Warner, R. G.; Harrison, H. N. \& Loosli J. $\mathrm{K}$. The stimulatory effect of sodium butyrate and sodium propionateon the development of rumen mucosa in the young calf. J. Dairy Science, 42:1600-5, 1959.

Sheahan, D.G.\& Jervis, H. R. Comparative histochemistry of gastrointestinal mucosubstances. Am. J. of Anat., 146:103-32, 1976.

Smithson, F. Grass opal in british soils. The J. of Soil Science, 9:48-55, 1958.

Spicer, S. S. Correlative study of the histochemical properties of rodent acid mucopolysaccharides. J. Histochemistry, 8:18-34, 1960.

Stinson, A. L. W. \& Calhoun, M. L. Sistema digestivo. In: Delman, H. D. \& Brown, E. M. Histologia Veterinária. Guanabara Koogan, Rio de Janeiro, 1982. pp. 164 - 211.

Sutton, J. D.; McGilliard, A. D. \& Jacobson, N. L. Functional development of rumen mucosa. I. Absorptive ability. J. of Dairy Science, 46:426-36, 1963.

Tamate, H.; McGilliard, A. D.; Jacobson, N. L.; Getty, R. Effect of various dietaries on the anatomical development of the stomach in the calf. $J$. of Dairy Science, 45(3)408-9, 1962.

van Soest, P. J. Nutritional Ecology of the Ruminant. 2a. ed. Copyright: Cornell University, 1994. p. 476.

Wardrop, I. D. Some preliminary observations on the histological development of the forestomachs of the lamb; the effects of diet on the histological development of the fore stomachs of the Janm. during post-natal life. J. of Dairy Science, 57:343-9, 1961.

Willems, G. \& Gerard, D. Étude histochimique comparée des glycoprotéines et polysaccharides intracellulaires de I'epthelium et des glades gastriques chez I'homme et chez diverses espécies animales. Acta GastroEnterologica, 32:211-25, 1969.

Dirección para correspondencia:

Prof. Dr. Célio de Sousa Rodrigues

Departamento de Morfologia

Universidade Federal de Alagoas

Maceio - $\mathscr{A L}$

BRASIL

Received: 17-08-2006

Email:celiofernando@yahoo.com.6r 